\title{
Challenges of Volcanic Crises on Small Islands States
}

\author{
Jean-Christophe Komorowski, Julie Morin, \\ Susanna Jenkins and Ilan Kelman
}

\begin{abstract}
Island communities frequently display specific risk-related characteristics that are attributable to the island locations of volcano-affected communities, in terms of exposure, vulnerability and living with the volcanic risk. This chapter examines volcanic crisis response and communication in island communities. We analyse lessons from volcanic crises in 1976 at $\mathrm{La}$ Soufrière (Guadeloupe, France), in 2005 and 2006 at Karthala (Grande Comore, Comoros), and in 1995 at Fogo (Cape Verde). Our analysis underscores the strong influence of deep-seated causes (historical, political, cultural, social, economic, and environmental) on the success and failure of volcanic risk communication, all of which are affected by island characteristics. The case studies demonstrate the intensity of politics that manifests in these instances - perhaps because of, rather than despite, the smallness and tightness of the communities, amongst other island characteristics. Consequently, improved information and less uncertainty would not straightforwardly lead to better communication or more harmonious acceptance of decision-making processes and of decisions.
\end{abstract}

J.-C. Komorowski ( $\bowtie)$

Institut de Physique Du Globe de Paris, Université Paris Diderot (Sorbonne Paris Cité), UMR CNRS 7154, Equipe "Systèmes Volcaniques" 1, Rue Jussieu, Paris 75238, Cedex 05, France e-mail: komorow@ipgp.fr; jeanchristophe. komorowski@gmail.com

J. Morin

Laboratoire de Géographie Physique, UMR 8591, Université Paris 1 Panthéon-Sorbonne, Meudon,

France

e-mail: julieapi@yahoo.fr

J. Morin

Institut de Physique Du Globe de Paris, UMR CNRS

7154, Equipe "Systèmes Volcaniques", Paris, France

\section{S. Jenkins}

School of Earth Sciences, University of Bristol, Bristol BS8 1RJ, UK

e-mail: Susanna.Jenkins@bristol.ac.uk

\section{Kelman}

Institute for Risk and Disaster Reduction and Institute for Global Health, University College London, Gower Street, London WC1E 6BT, UK e-mail: ilan_kelman@hotmail.com

\section{Kelman}

Norwegian Institute of International Affairs (NUPI), Oslo, Norway 
One fundamental point is the need to engage with - not just consultlocal populations regarding risk communication and decision-making, tailoring messages to the various audiences, and being clear regarding what is known and not known, plus what is feasible to do to fill in knowledge gaps to support decisions. Ultimately, it is necessary to foster synergies with communities to ensure that no party or knowledge dominates, but instead information is exchanged leading to decisions and decision-making processes that are better understood and accepted by all who are involved. Living with volcanic risk thus means working with communities on their terms.

\section{Keywords}

Small island - Volcanic eruptions - Volcanic risk - Crisis management • Guadeloupe - La Soufrière - Comoros $\cdot$ Karthala $\cdot$ Fogo $•$ Cape Verde

\section{Introduction}

This chapter examines volcanic crisis response and communication in island communities. We analyse lessons from volcanic crises in 1976 at La Soufrière (Guadeloupe, France), in 2005 and 2006 at Karthala (Grande Comore, Comoros), and in 1995 at Fogo (Cape Verde). Our analysis underscores the strong influence of deep-seated causes (historical, political, cultural, social, economic, and environmental) on the success and failure of volcanic risk communication, all of which are affected by island characteristics.

Island communities frequently display specific risk-related characteristics that are attributable to the island locations of the volcano-affected communities, in terms of exposure, vulnerability and living with the volcanic risk (Lewis 1999, 2009; Méheux et al. 2007; Mercer and Kelman 2010; Morin 2012; Pelling and Uitto 2001). In fact, research and experience from island communities has been a significant foundation for understanding risk, disaster risk reduction, and disaster response, particularly in volcanic contexts (de Boer and Sanders 2002; Gaillard 2008;
Keesing 1952; Kelman et al. 2011; Pattullo 2000). Regarding specific vulnerabilities:

- small land size, despite large ocean territory, can mean that even moderately sized volcanic hazards threaten the entire territory and population, causing difficulties in planning for risk management, and often needing to consider the possibility of permanent evacuation of the entire island,

- relative inaccessibility and remoteness from centres can often cause problems for decision-making,

- small populations make it difficult to have local experts for all disciplines required, yet small populations do not necessarily increase the community's homogeneity meaning that diverse cultural responses could still be expected.

Regarding living with the risk:

- tight, kinship-based communities can build inherent trust, sometimes supporting rapid information dissemination and response, 
- communities with no option but to live in close proximity to the volcano can build up local knowledge regarding volcano behaviour, warning signs, and responses,

- small, diversified economies-including offshore livelihoods such as migration and remittances - can sometimes permit more nimble adjustment to crisis.

- The volcano could have provided a baseline of robust livelihoods, such as through agriculture and tourism, meaning that the population might have resources available to support themselves for some time.

The legacy of the island case studies presented here, over the decades during which they ensued, has significant implications for crisis response plans and risk communication for potential future eruptions - or eruption threats. The lessons are outlined in terms of engaging with local populations regarding risk communication and decision-making, tailoring messages to the various audiences, and being clear regarding what is known and not known, plus what is feasible to do to fill in knowledge gaps to support decisions.

The bulk of this chapter is presented as the three case studies, with the lessons and island relevance woven into the descriptions. The final section synthesises some general points emerging and provides examples of ways forward.

\section{Case Study 1: La Soufrière de Guadeloupe, Guadeloupe, Caribbean}

Management of the volcanic crisis at La Soufrière of Guadeloupe in 1975-77 remains one of the most contentious in recent times (Fiske 1984; Komorowski et al. 2005; Beauducel 2006; Devès et al. 2015). The chronology of the phenomenology, and the actions taken by scientists and authorities to manage the crisis were summarized by Hincks et al. (2014). The mild but persistent seismic and fumarolic unrest that has slowly increased since 1992 at La Soufrière volcano (Komorowski et al. 2005; http://www.ipgp.fr/fr/ ovsg/bulletins-mensuels-de-lovsg; Komorowski et al. 2013b, 2014) has prompted renewed interest in geologic studies, monitoring, risk modelling, and crisis response planning (Komorowski et al. 2012, 2013a; https://sites.google.com/site/ casavaanr/) in order to learn from the 1975-77 crisis and improve the management and response to any potential future crisis at this volcano.

At least 6 phreatic explosive eruptions (1690, 1797-98, 1812, 1836-38, 1956 and 1976-77) have occurred at La Soufrière de Guadeloupe during the historical period since AD 1635. In contrast to previous phreatic eruptions of $\mathrm{La}$ Soufrière and elsewhere in the Caribbean, a significant period of increasing volcanic seismicity was recorded and felt in Guadeloupe starting in July 1975, one year prior to the onset of the eruption. This unprecedented and rapidly escalating level of recorded and felt seismicity (Dorel and Feuillard 1980; Feuillard et al. 1983; Feuillard 2011), which in June 1976 reached levels that were 175 times the baseline monthly rate, was not accompanied by any modification of fumarolic activity. The eruption began with an unexpected explosion on 8 July 1976. The subsequent 9-month long period of explosive and ash-venting activity was interpreted as a still-born or failed magmatic event (Feuillard et al. 1983; Villemant et al. 2005; Boichu et al. 2011). Syn-eruptive degassing $\left(\mathrm{H}_{2} \mathrm{O}\right.$, minor $\mathrm{CO}_{2}$, $\mathrm{H}_{2} \mathrm{~S}, \mathrm{SO}_{2}$ ) with acid condensates ( $\left.\mathrm{HCl}, \mathrm{HF}, \mathrm{Br}\right)$ led to moderate environnmental impact with short-term public health implications.

A major controversy emerged among the scientific community (Fiske 1984) as to whether fresh juvenile magmatic components could be recognised in the ejecta, thus raising the probability of a transition from a purely phreatic, non-hazardous scenario to a highly hazardous magmatic 1902 Mount Pelée-style explosive scenario. The scientific disagreement was widely echoed in the media (Loubat and Pistolesi-Lafont 1977; Farugia 1977; De Vanssay 1979; Figs. 1 and 2). On August 15, the emergency plan was enacted by the authorities based on the systematic increase in seismicity and magnitude of explosions. About 70,000 people were evacuated from all of southern Basse-Terre for about six months until December 15, 1976 (Préfecture de 
Guadeloupe 1977; De Vanssay 1979; Lepointe 1984, 1999). This evacuation remains controversial today; however, regardless of the interpretation of the eruption's evolution, evacuation of the population in the areas closest to and downwind from the erupting volcano was necessary due to the degassing and ash fallout.

The cost of the preventive evacuation was estimated at $60 \%$ of the total annual per capita Gross Domestic Product (GDP) of Guadeloupe in 1976 (Lepointe 1984, 1999; Blérald 1986; Kokelaar 2002) excluding the losses of uninsured personal assets and open-grazing livestock. Hence, this eruption and the evacuation that ensued rank amongst the most costly for the 20th century (Annen and Wagner 2003) although the eruption itself did not cause any fatalities. A few years before the eruption, a public policy was implemented to move the banana export port facilities of the Basse-Terre harbour highly exposed to Caribbean swells to the more sheltered harbour and economic capital Pointe-à-Pitre. The widespread long-lasting evacuation reinforced this shift to Pointe-à-Pitre, contributing to the demise of the economy of the administrative capital, Basse-Terre, and to the feeling among the population of bitterness and of being forsaken.

Lack of a comprehensive and integrated monitoring network prior to and during the crisis, the then-limited knowledge of the eruptive history, and a tendency of caution exacerbated by the memory of past devastating Caribbean eruptions (e.g. the devastating explosive eruptions of Montagne Pelée in May 1902 and of Soufrière of St. Vincent in April 1902) all contributed to a high degree of scientific uncertainty alongside a publically-expressed lack of consensus and trust in available expertise. Hence, analysis, forecasting, and crisis response were highly challenging for scientists and authorities in the context of escalating and fluctuating activity as well as societal pressure in a small island community (Komorowski et al. 2005; Beauducel 2006). Given the uncertain evidence and the absence of scientific consensus on the likely outlook, and the lack prior to the crisis of a well-defined and accepted volcanic emergency response plan, the authorities felt impelled to adopt an approach involving zero risk of casualties from the volcano-without fully considering other social risks emerging due to the evacuation.

A binary manichean approach appeared in the scientific discourse through a major conflict between two leading, authoritative scientists, C. Allègre and H. Tazieff, that unravelled and escalated in the media and public (Farugia 1977; Loubat and Pistolesi-Lafont 1977; De Vanssay 1979). Within the context of the socio-cultural frustrations the islanders experienced, feeling to be an unimportant appendage to the mainland, the scientific disagreements engendered a distrust of mainland (colonial) science. The authorities expected and demanded that the scientists and volcanology would provide one clear answer, not a range of more likely or less likely outcomes. They operated in a binary framework and expected science to be precise, to provide the answers, and to render decisions easier.

In fact, this crisis epitomized the growing clash of scientific paradigms at the time: one of observational and intuitive empirical science, embodied by Tazieff, versus one of quantitative science relying on models and integrating a probabilistic framework and some degree of uncertainty, embodied by Allègre. In the end facing Hamlet's dilemma-will the eruption evolve into a paroxysmal explosive onset magmatic eruption or not (Fig. 1) - the manichean framework led to a very low acceptance of inherent uncertainty and the advocacy of the predominance and uniqueness of one or a few strands of evidence. The deep disagreement between opinionated scientists who often bypassed the responsible authority to speak directly to the population and the media-with the straightforwardness of attracting a substantial audience in a small, isolated community - thus vented the scientific debate directly to the public without critical and consensual appraisal, forcing authorities to seek alternative advice. Many "special" advisors provided their own cast on the uncertain processes developing at the volcano. This significantly undermined the integrity of the scientific judgement and the trust amongst 
(a)

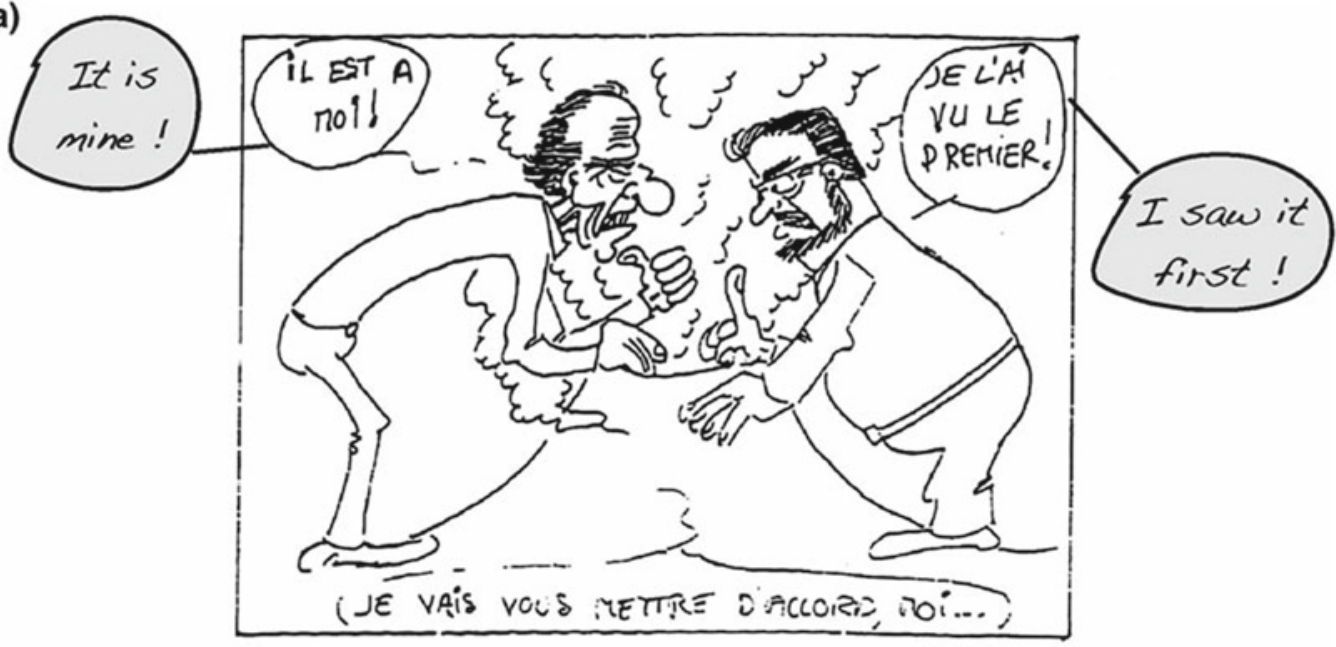

I will make you agree, me!

(b)

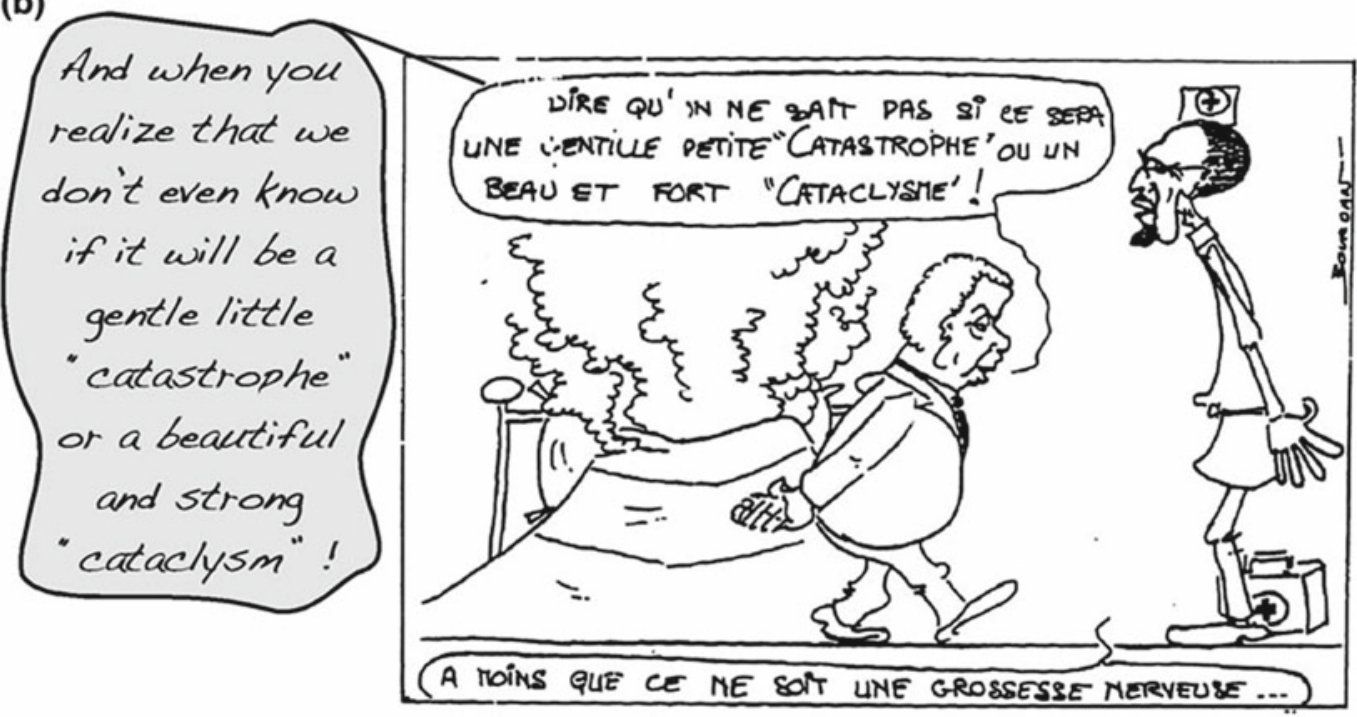

Unless it turns out to be a hysterical pregnancy ...

Fig. 1 a The Préfet Aurousseau and M. Feuillard reflect at the bedside of La Soufrière. After a drawing by $\mathrm{C}$. Maillaud-Bourdan, published in France-Antilles on 27 September 1976; b H. Tazieff and R. Brousse quarrel over
La Soufrière. After a drawing by C. Maillaud-Bourdan, published in Guadeloupe 2000 No. 46, October-November 1976 (Taken from De Vanssay 1979) experts, decision-makers, and the exposed population.

In Guadeloupe, the societal perception and translation of these conflicting schools of scientific thinking saw the rise of the image of maverick, anti-conformist, and heroic scientists (e.g. Tazieff) against more precautionary, conservative scientists (e.g. Brousse and Allègre). A perceived contrast emerged of free, independent scientists fighting for a just cause (the 
former) versus scientists who became or were perceived to be aligned with a political agenda and to a system of governance (the latter). The public debate thus became political and polarized based on opposing "truths" from contrasting scientific expertise (Fig. 2) rather than on how science could help constrain epistemic and aleatory uncertainty in order to foster improved decision-making despite uncertainty. This situation acted as an ideal crucible for fuelling a media-hyped controversy on the crisis and its management (Loubat and Pistolesi-Lafont 1977; De Vanssay 1979; Farugia 1977) that was easily prone to wild conspiracy theories. The volcano hence became a catalyst of accumulated island-mainland disputes - a way to engage in a mutual catharsis of the remains of France's colonialist past in the region and the sequels in its post-colonialist policies.

The controversy and the conflation of science with long-standing political grievances had significant lasting effects on national and international volcanology. A portion of the population still collectively deems that the evacuation was unnecessary or that the need was largely exaggerated, with many believing that the politics of shifting towards Pointe-à-Pitre superseded science with the justification of applying at the maximum precautionary principle. This has fuelled conspiracy theories and perceptions that the hazard and risk assessment was imported from the mainland, that the scientists' mentality was disconnected from the localised island reality, and that it served a political agenda that had

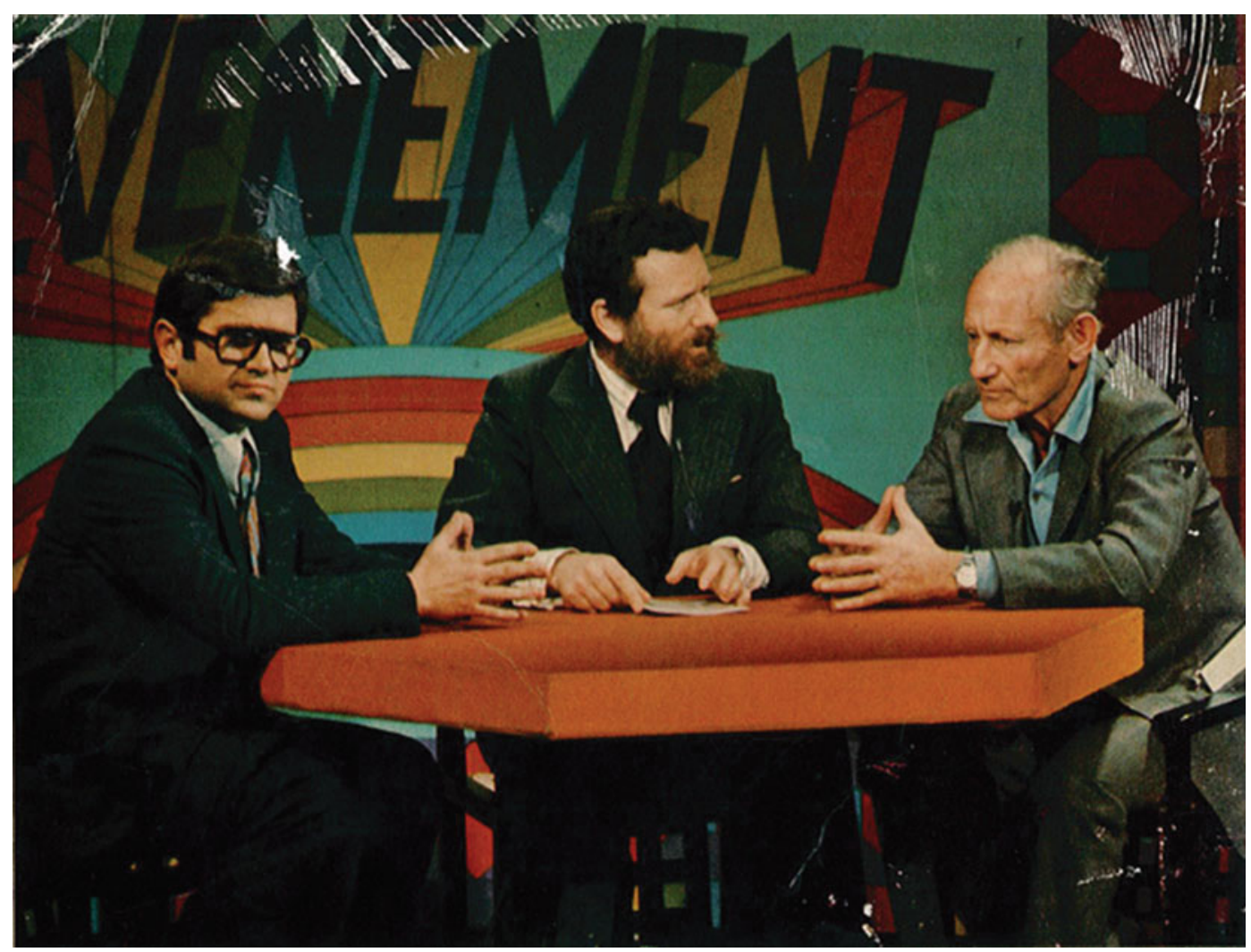

Fig. 2 Photo taken from a television (TF1) debate on 11 November 1976 between C. Allègre, then Director of the Institut de Physique du Globe de Paris (left) and volcanologist H. Tazieff (right) with J. Besançon as the moderating journalist (Taken from Loubat and Pistolesi-Lafont 1977) 
started prior to the eruption but was fortuitously reinforced by the eruption. In fact, there was a blatant underestimation by authorities, scientists, and media, that for the evacuated and affected population, the volcano being the source of their distress and livelihood loss rapidly faded behind the curtain of long-nurtured socio-political frustrations and issues of cultural identity and island empowerment.

The eruption marked a tipping point in the recent history of Guadeloupe and symbolized its unresolved dilemmas and injustices. The volcano became an excuse to publically express a profound dissatisfaction in public authorities and policy, in the centralized mainland-focused system of governance. All protagonists failed to recognize that politics became the real driver of risk perception, the local agenda, and the aspirations of civil society.

However, positive consequences included a major increase in national funding for volcano monitoring and research. Lessons learned significantly improved volcano crisis management worldwide and notably for the nearby 1979 St. Vincent eruption. In the context of increased population density on the volcano's flanks and ongoing major development plans for southern Basse-Terre, even a 1976-77 style eruption will likely pose major challenges to authorities and decision-makers despite the presence of a highly sophisticated monitoring network and the vast knowledge subsequently acquired about La Soufrière volcano. Thus, this infamous crisis exemplified the need for a structured and transparent approach to evidence-based decisionmaking in the presence of substantial scientific uncertainty (Aspinall 2010; Aspinall and Cooke 2013; Aspinall and Blong 2015).

\section{Case Study 2: Karthala, Grande Comore, Comoros, Indian Ocean}

Union of Comoros is a volcanic archipelago (Fig. 3) and one of the world's smallest and poorest countries (Taglioni 2003; UNDP 2014). Emigration is assumed by many to be the only solution to escape poverty, so 200,000
Comorians live in France (Da Cruz et al. 2004), which was Comoros' colonial power until 1975. When independence was proclaimed, France allegedly illegally kept Maore (one of the four Comorian Islands) under its political control, creating a legal battle with Comoros (Oraison 2004). Moreover, the governments of each island (Nzwani, Mwali, and Ngazidja) regularly contest their level of autonomy from the Union federal government. Consequently, it is difficult to define the exact prerogatives attributed to the islands' and Union's governments, including those linked to the volcanic crises management (Morin and Lavigne 2009).

Grande Comore Island (or Ngazidja; $1148 \mathrm{~km}^{2}$ ) is dominated by Karthala, an active basaltic shield volcano which has erupted, on average, every seven years in recent decades. Volcanic hazards threaten the population, as effusive or explosive eruptions may impact upon the whole island (Bachèlery and de Coudray 1993), including coastal villages, Hahaya international airport, and the capital, Moroni (Morin et al. 2016). Electricity and telephone networks are easily and often saturated, disrupted, or inaccessible in some parts of the island that are out of range from the communications relay. Chouaybou (2010) underlines that after each major event on the island, diaspora members call their families, contributing to the network's saturation. As with other Comorian infrastructure, the monitoring network of the local volcano observatory (Observatoire Volcanologique du Karthala-OVK) is poorly developed and difficult to maintain, due to financial, technical and human resource constraints (Morin et al. 2009, 2016).

Additionally, within this context, Morin and Lavigne (2009), Morin (2012), Morin and Gaillard (2012) and Kelman et al. (2015) describe how some people consciously increase the volcanic risk level in their community to have an easier access to livelihoods. For example, some villagers repeatedly steal solar panels from the OVK monitoring network for easier access to electricity. Some other villagers vandalize the OVK network to contest foreign post-colonial "domination" (as the network was mainly funded 

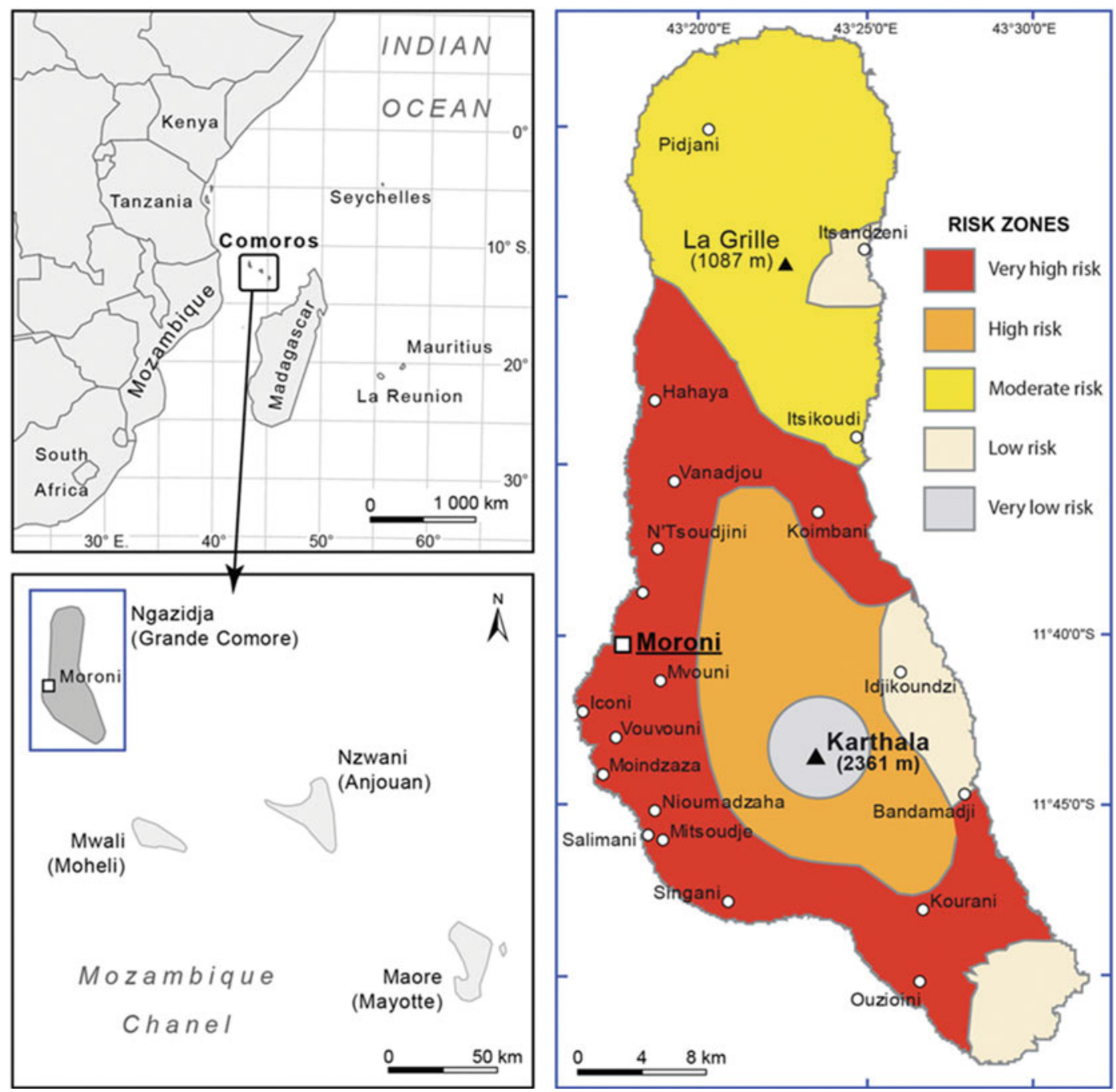

Fig. 3 Volcanic risk and hazards zonation for Grande Comore (adapted from Nassor 2001)

by France), or to claim that their deep links with the volcano and their customary chiefs' knowledge are enough to face the volcanic threat. Once the network is degraded, OVK has much reduced capacity to monitor and interpret seismic or volcanological activity. While authorities and OVK have targeted this issue in their last risk awareness campaigns, thefts and degradations continue.

The 2006 eruption demonstrated both the authorities' disorganization in facing crises and OVK's incapacity to deliver prompt, clear and updated information (Morin et al. 2009), making the communication process really poor. People were informed of the eruption mainly by word-of-mouth or by their own observations; only a third of the population was warned by the media. The lack of warning systems, combined with an absence of any consistent prevention information, created anxiety amongst islanders and affected their responses, negatively impacting the crisis management. One consequence was that the OVK scientific team faced harder and more detailed communication tasks than expected (Fig. 4).

Several 'critical' periods for the OVK team were reported, the worst one being from 28 May 21:10 to 29 May 02:00, just after the eruption's 

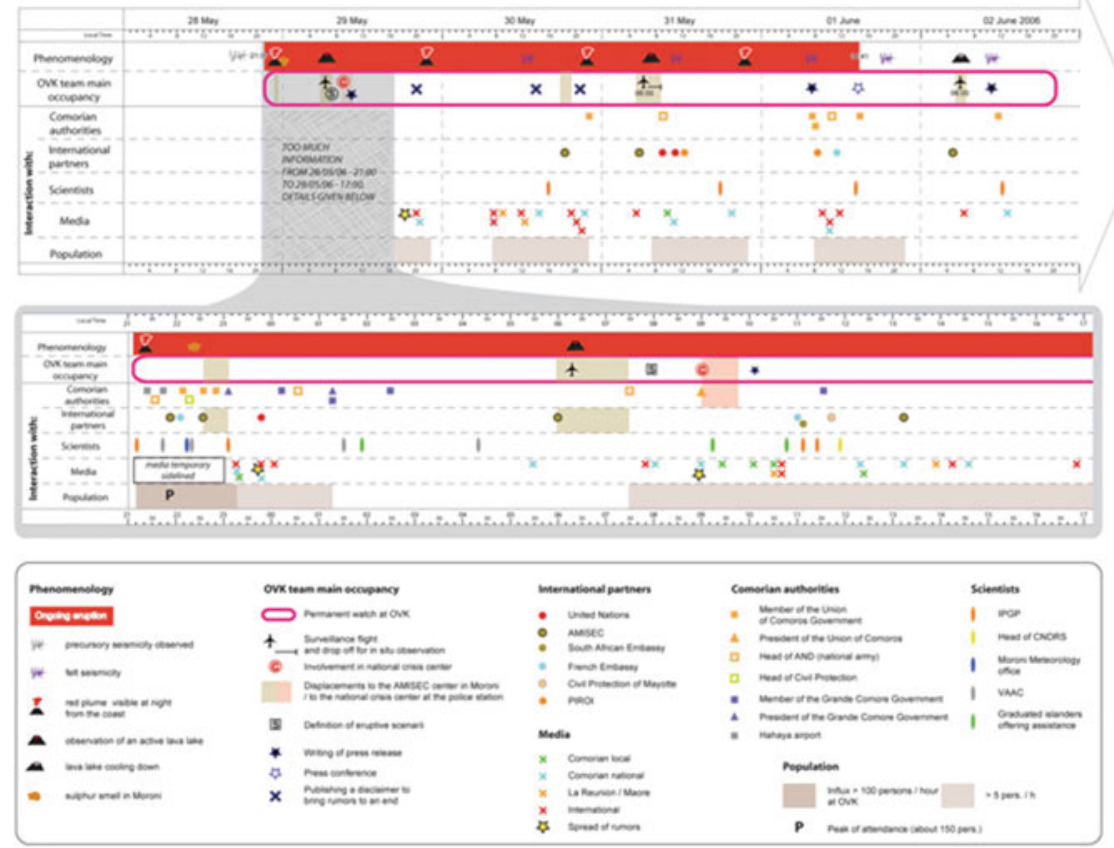

Fig. 4 Main components in the official schedule of the local volcano observatory team during the May 2006 eruption of Karthala (translated from Morin 2012). Due to the multiple and constant internal and external interactions of the six people involved in the May 2006 crisis management at OVK, it is estimated that $30-40 \%$ of official meetings were not listed. Otherwise this register does not include exchanges with the officials who came to enquire personally about the situation, nor the constant calls received by the OVK team from inhabitants requesting or offering information. This 'informal' trade is a flow roughly equivalent to the 'formal' one

beginning. OVK faced 30 meetings and interviews with authorities of both Island and Union governments, and an agglomeration of hundreds of civilians at the OVK office, in addition to dozens of phone calls saturating OVK phone facilities, while no localization of the eruptive activity nor a scenario of its evolution was possible to provide at that time. People suspected that scientists did not communicate because of serious ongoing problems while the overwhelming number of journalists was difficult for the OVK team to manage, so journalists were sidelined for a few hours. The first information was given soon after 23:00, as soon as it had been decided to fly over the volcano at dawn in order to observe the nature and location of the eruption. Rumours circulated by a few local and international media (such as "lava is flowing down the slopes of Karthala, threatening thousands of Comorians") immediately spread within villages and then to the international news. OVK team was forced to monitor the media three times a day (dawn, noon, and evening) to be able to quickly deny any wrong information. A protocol was established to improve communications efficiency, one of the rules being to limit the number of scientists communicating with the media: one in Shikomori (the local language) and another in French and English.

The second main problematic period was on 29 May from 09:00-12:30, just after the first flight over the volcano. Once more, rumours about the evolution and implications of the eruptive activity spread on the island. This indicates that the information given by the OVK team was interpreted incorrectly by some journalists. 47 interviews were given during this 
five-day-eruption, and OVK had to deny three rumours spread through the media. A disaster communication handbook for journalists was conceived after the 2006 eruption, based on the DFID handbook (2003).

The abnormally high number of interlocutors was difficult to manage for the OVK team, showing that the theoretical procedures described in the "Karthala Plan", 37-page appendix to PNPRU [National Emergency Preparation and Response Plan (Union des Comores 2004)], were not known. In fact, PNPRU has not been widely disseminated or updated since it was created in 2004. For example, in 2006 , it did not contain the updated phone numbers of main risk management stakeholders. Moreover, due to Comoros' colonial past, PNPRU is modelled on French plans without taking into account island contexts. Its operational specification sheets are not necessary adapted to the traditional oral cultural context in Comoros for dealing with locals during a crisis (Morin et al. 2009). Warning dissemination and general information, for example, could rely more on the active local religious networks and non-profit organizations.

Paradoxically, because the monitoring network was still out of order, and despite its team already being overwhelmed, OVK had no other solution than to ask, through a media announcement, that the inhabitants deliver to OVK any testimony about seismicity or suspected volcanic activity. In response, inhabitants made dozens of phone calls to report felt phenomenon (e.g. smells and seismicity) and new "eruptive activity" (most of the time, bushfires). Calls peaked from May 30 to June 1 as earthquakes were felt in the Bahani area, a few kilometres north of Moroni.

The main difficulties in volcanic crisis communication on Grande Comore are mainly due to Comoros being a poor, small, remote island country. The small population implies difficulties in finding local experts in all fields, so that volcanological monitoring and understanding relies on foreign researchers from $\mathrm{La}$ Réunion and mainland France. The whole territory is threatened by volcanic hazards while communication networks are very weak. OVK's inability to provide information, the inhabitants' and authorities' lack of preparedness, and the alarmist news disseminated by the media are amongst main weaknesses, leading to a failure of crisis management and crisis communication on Grande Comore during the last volcanic crises.

\section{Case Study 3: Fogo Volcano, Cape Verde, Atlantic Ocean}

Fogo volcano and island, within the Cape Verde archipelago of hotspot volcanism, lie approximately $600-800 \mathrm{~km}$ west of Senegal in Africa. Fogo Island is around $30 \mathrm{~km}$ in diameter and is formed entirely of the large stratovolcano of Fogo, which rises $2829 \mathrm{~m}$ above sea level and is the most prominent and only historically active volcano in Cape Verde. An approximately 9-km wide lateral collapse structure dominates the island, and is open to the east with very steep headwalls of up to $1 \mathrm{~km}$ (Fig. 4; Day et al. 1999). The central cone of Pico do Fogo rises more than $1 \mathrm{~km}$ above the partially infilled collapse scar and is home to 'Chã das Caldeiras' residents. One of the major hazards for Chã residents, aside from drought and a lack of basic services, is rockfalls from the steep headwalls; more direct volcanic eruption hazards (Fig. 5) have typically been of lesser concern.

Historical accounts indicate that Fogo volcano experienced regular eruptions during the early stages of Portuguese settlement (Fonseca et al. 2003) and that the summit cone of Pico do Fogo last erupted in 1680, producing large ash falls that rendered agricultural lands temporarily unusable and triggered mass emigration from the island (Ribeiro 1960). Recent activity has been more subdued with direct experience restricted to the effusive eruptions of 1951, 1995, and 2014-2015 that occurred from subsidiary flank vents and fissures near the base of Pico (Faria and Fonseca 2014). 


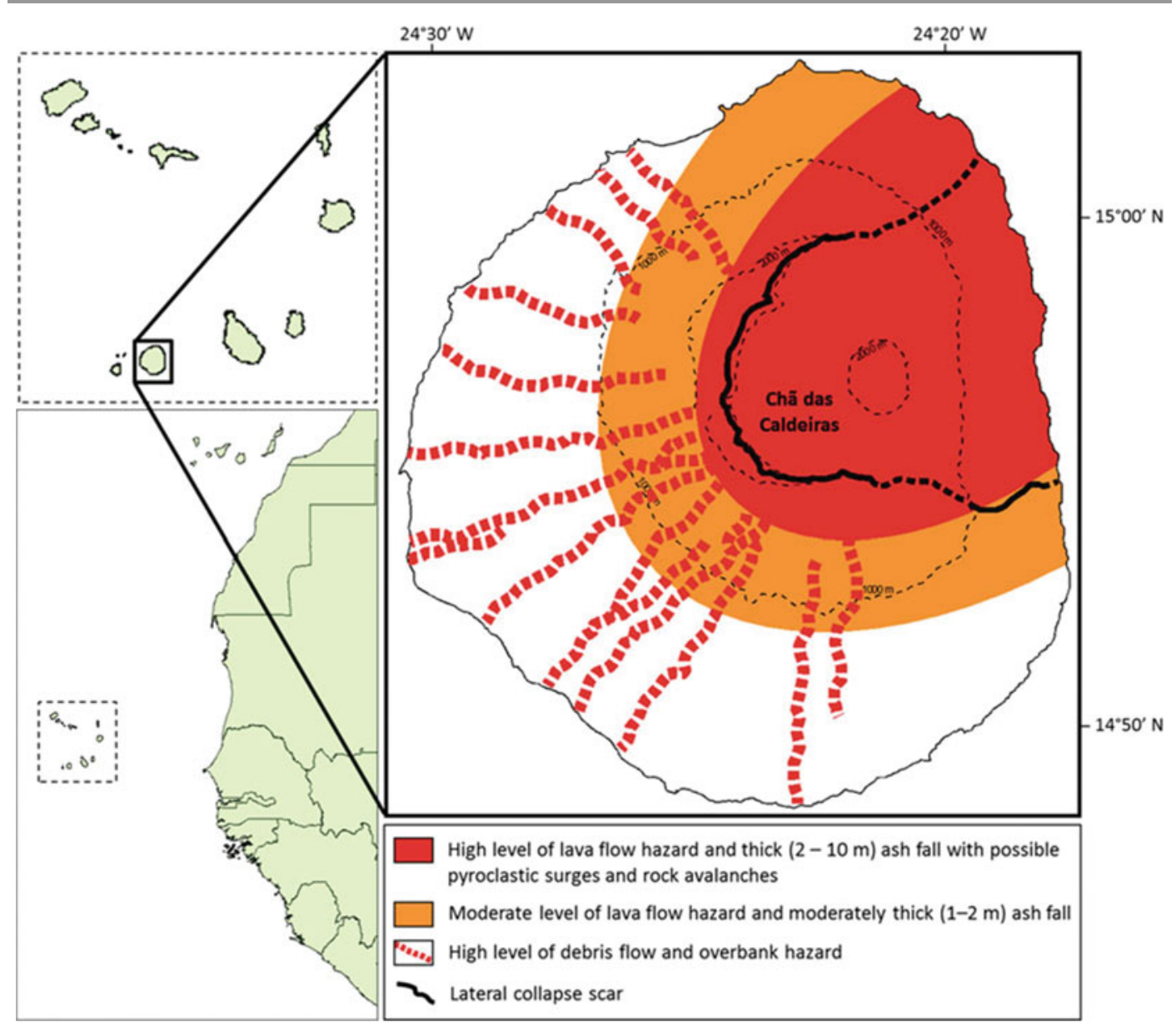

Fig. 5 Location of Fogo Island in the Cape Verde archipelago, with inset: provisional volcanic hazard map for a large explosive eruption similar to the 1680 event (Day 2009)

Official maps outlining potential future volcanic hazards are not publicly available for Fogo; however, Day and Faria (2009) identify three preliminary scenarios in an outline hazard analysis: (1) A continuation of post-1785 effusive activity on volcanic fissures within Chã das Caldeiras; (2) More intense and frequent fissure eruptions similar to those during the 17th and 18th centuries; and (3) A large explosive eruption from the summit of Pico do Fogo as in 1680 (Fig. 4). Additionally, the neighbouring island of Brava, $20 \mathrm{~km}$ to the west of Fogo shows geological evidence of Plinian volcanism and, in certain wind conditions, large eruptions from Brava may be expected to deposit significant ash falls on Fogo Island (Jenkins et al. 2014).
Communication of the volcanic hazard and risk on Fogo Island consists predominantly of top-down approaches supported by local monitoring institutions and the army-led National Civil Protection Service (SNPC), which was formed after the eruption in 1995. At the time of the 1995 eruption, Chã das Caldeiras was home to approximately 1,300 people in three villages; prior to the 2014 eruption, this number was estimated at nearly 1,500 (Global Volcanism Program 2014). A further 11,000 people in a number of villages on the steep eastern flanks of Fogo are exposed to overspilling flows.

Following intermittent, felt earthquakes through late March and early April 1995 at Fogo, a fissure eruption began on the night of 2-3 April 
1995. Lava fountaining and associated flows cut off the main road into Chã and over the next week lava flows destroyed a village, water reservoir and a few square kilometres of fertile agricultural land (Fig. 6a). On 8 April, remaining residents were ordered to evacuate the Chã das Caldeiras or face arrest (Bulletin of the Global
Volcanism Network 1995). The eruption ended around 28 May 1995 and in the years that followed communities and associated services such as health and education were permanently relocated outside of the collapse scar.

Within two years, Chã had been repopulated and prior to the 2014-2015 eruption was home to

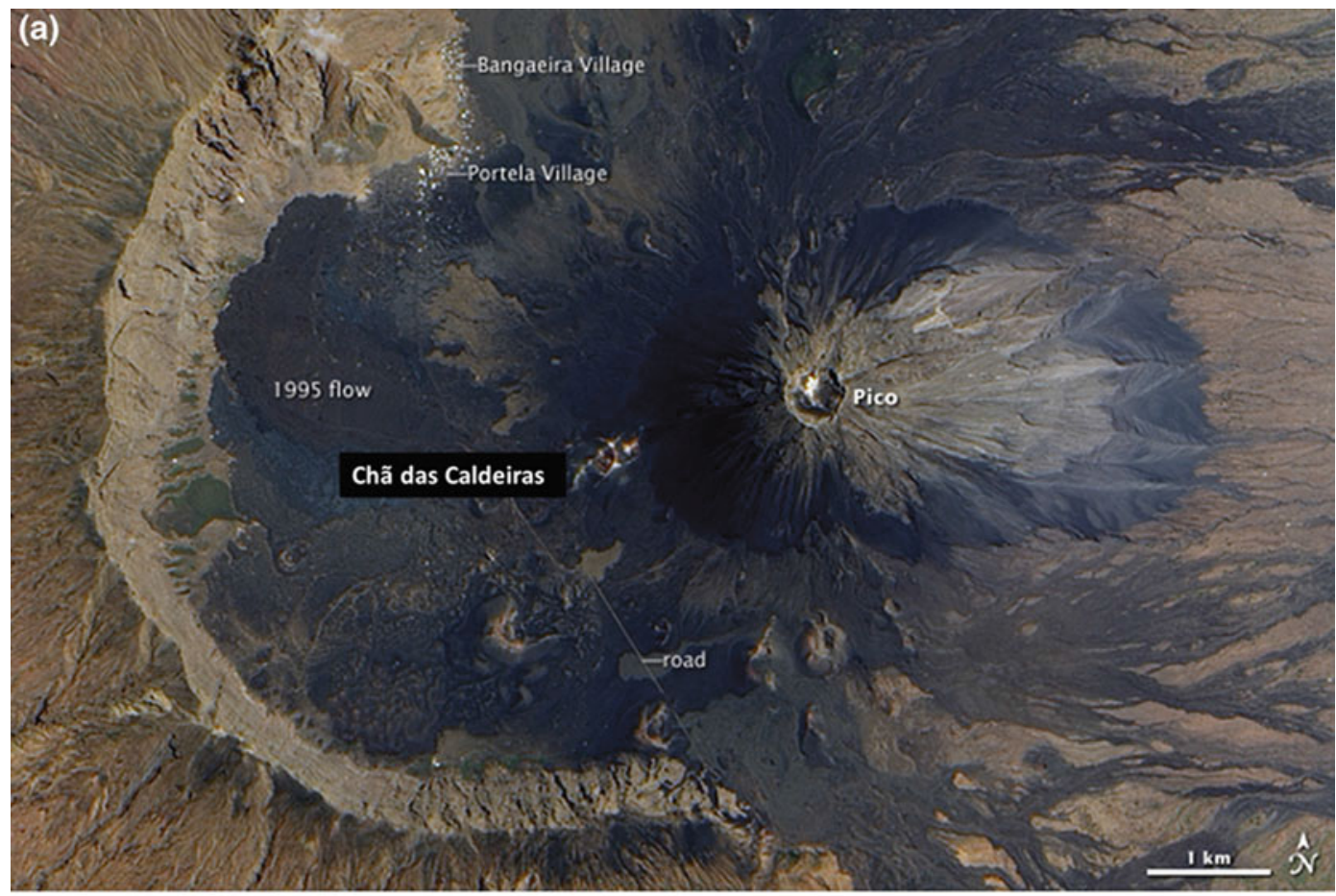

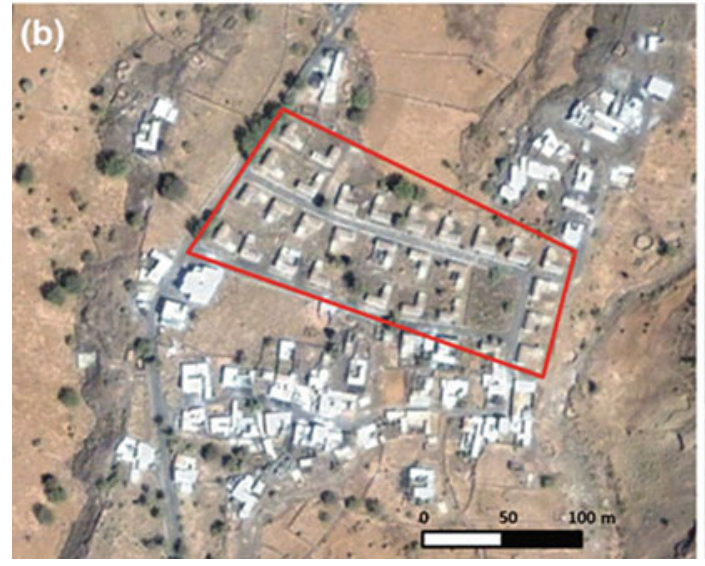

Fig. 6 a A 2009 NASA Earth Observatory satellite image of Chã das Caldeiras showing the remaining villages and the extent of the 1995 lava flows; b 1995 permanent relocation sites within the red outline in the

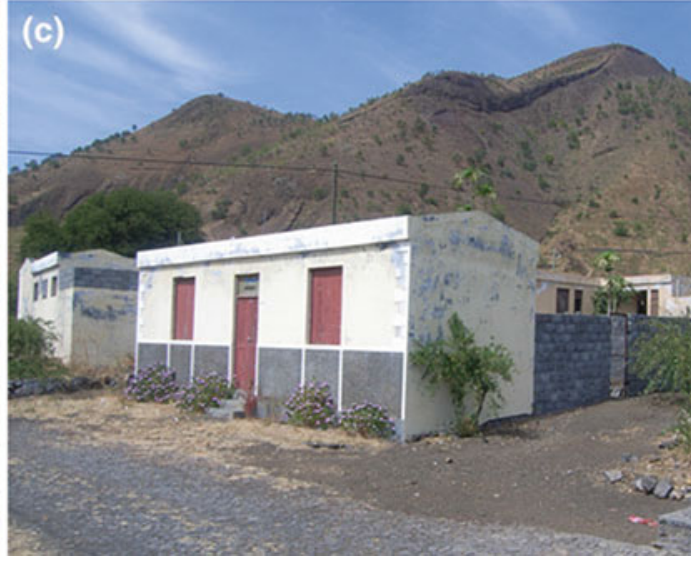

village of Achada Fuma (image Google Earth); c A building within the now partly abandoned relocation site (photo S. Jenkins) 
around 800 people with most of the population living in Portela and Bangeira (Fig. 6a), as well as a burgeoning wine and tourism industry (Jenkins et al. 2014). The failure of people to permanently relocate following the 1995 eruption is attributed to the close social and economic ties that Chã residents have to their place of origin and because of unsuitable relocation sites that lacked sustainable sources for livelihood. Relocation sites, subsidised by the German government, were positioned outside of the collapse scar in areas of relatively low hazard to the south of the island; however, they provided very small living quarters and limited-to-no agricultural land (Fig. 6b, c). For the family-centred communities for whom farming was the main source of livelihoods for sustenance and trade, these sites offered an unviable alternative to Chã das Caldeiras (Fig. 7).

From November 2014 to February 2015, Fogo produced another effusive eruption similar to that of 1995. The eruption produced explosions and ash emissions, lava fountains and fast-moving lava flows moving up to $20 \mathrm{~km} / \mathrm{hour}$ ). All of the Chã residents were evacuated with lava flows destroying more than $90 \%$ of the main villages, Portela and Bangeira, a large area of agricultural land, communication poles and the only road into the area (Fig. 5). Intermittent ash explosions dispersed and deposited ash in the main city of São Filipe and across agricultural crops on the island; the airport and tourism industry were also impacted. As of writing, it is unclear if Chã residents will be able to return, but near-complete reconstruction would be required to enable repopulation of Chã.

One of the key issues facing risk communication on Fogo appears to be prioritising concerns about livelihoods for the affected communities. On Fogo, eruptions are not the major concern for at-risk communities; populations are more concerned with a lack of basic services, drought, and associated food shortages. The implementation of Fogo National Park in 2003, which aimed to protect the natural environment and regulate tourism through land-use and livestock restrictions, caused conflict between authorities and Chã residents who claimed that their livelihoods were adversely affected by such restrictions (Texier-Teixeira et al. 2013).

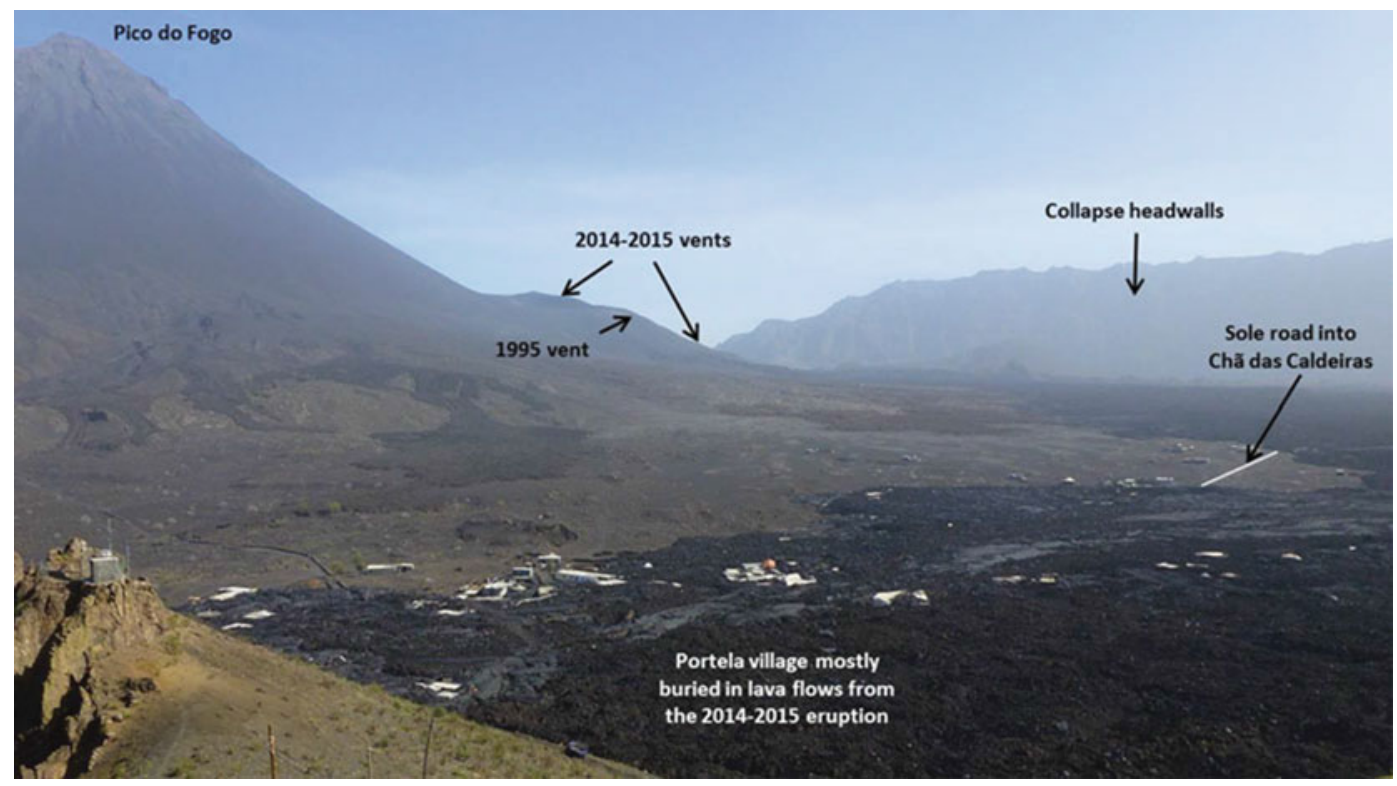

Fig. 7 Annotated photograph of December 2014 lava flows that buried Portela village. The view is looking approximately due South with Pico do Fogo to the left of the image and the steep collapse scar walls to the right. (Photo S. Jenkins) 
More recent risk communication efforts by the authorities have included evacuation and communication exercises with a community-based focus. They have been carried out by SNPC and one of the local monitoring institutions, the National Institute of Meteorology and Geophysics, with partial support from the Italian Civil Protection and MIA-VITA (a European research project). Unfortunately, the exercises found that tour guides, women, and farmers, some of the most important groups in Chã das Caldeiras, were difficult to engage with the exercises and decision-making (Texier-Teixeira et al. 2013). Future volcanic risk management and communication therefore needs to first address socio-economic vulnerabilities and priorities in order to carry out fully successful risk reduction measures. The government of Cape Verde currently has plans to create a local Fogo civil protection agency to allow for more community-based activities, although this is not yet operational.

The 2014-2015 eruption and the destruction of villages within Chã may have changed the way volcanic hazard and risk at Fogo are communicated from that suggested by the pre-eruption studies. Future studies should investigate.

\section{Risk and Crisis Communication for Island Communities}

Island communities are frequently portrayed as being tight-knit with few people being strangers to each other, suggesting the potential that crisis response is more efficient because information travels quickly, people trust each other, and social structures are more nimble. The three case studies demonstrate that plenty of truth exists in such assumptions, but that does not necessarily ease the situation. Instead, as always with risk- and disaster-related communication and knowledge-policy interfaces, multi-faceted layers intertwine and information flow is not a linear, predictable process (Barclay et al. 2008; Gaillard and Mercer 2013; Weichselgartner 2003).

In all three cases presented here, it was not possible to reach a common denominator and representation and perception of what a volcanic eruption is, what are the associated risks, what are the timescales of volcanic processes and the necessary timescales of risk prevention policies, and what exactly is happening and could happen in the particular situation under question. The media's role was particularly poignant, with difficulties often resulting for the scientists because the media and scientists did not have a trusting relationship. Particularly in small communities, it is important to avoid viewing the media as a separate or hostile entity, but instead to work them so that their needs are met but reports are accurate and informative. The relationship cannot be built during a crisis, but must start immediately so that all parties involved have already built an understanding of needs when the crisis emerges (see also Barclay et al. 2008; DFID 2003). The communication challenges can further be overcome through expanding the capacity and responsibility of the scientific community to explain its paradigms, its methodologies, different types of uncertainty (epistemic and aleatory), and the limitations to and for different audiences, namely the authorities, decision-makers, crisis responders, economic actors, the public, and the media.

An example from Guadeloupe aiming to do so is the widespread public dissemination of a monthly activity bulletin by the Observatoire Volcanologique et Sismologique de Guadeloupe (OVSG-IPGP) that was launched in 1999 and has continued ever since (http://www.ipgp.fr/fr/ovsg/ bulletins-mensuels-de-lovsg; http://www.ipgp.fr/ fr/ovsg/actualites-ovsg). A tri-monthly similar bulletin is issued by the Observatoire Volcanologique et Sismologique de Martinique (http://www.ipgp.fr/fr/ovsm/bilans-trimestrielsde-lovsm). It would be useful to enact studies to determine the reach of these bulletins and the understanding by and interest of those who read them. What information and styles could the bulletins include which would appeal to a wider readership and ensure that uptake of the information is increased? Such work will enhance participatory science, as with the media establishing a baseline and trust before an emergency so that crisis communication should be smoother and more widely accepted. 
As well, as science evolves, new scientific approaches could assist in better integrating different sectors into volcanic crisis communication processes. Again from Guadeloupe, a recent retrospective Bayesian Belief Network analysis of the unrest of La Soufrière volcano in 1976 (Hincks et al. 2014; Komorowski et al. 2015) demonstrates that a formal evidence-based case could have been made to support the authorities' concerns about public safety and the decision to evacuate in 1976. Development of such novel probabilistic formalism for decision-making could help to reduce scientific uncertainty and better assist public officials in making urgent evacuation decisions or policy choices (Woo 2011) should the mild but sustained and slightly increasing seismic and fumarolic unrest that began in 1992, and further developed in 1998, evolve into renewed eruptive activity (OVSG-IPGP 2015; Villemant et al. 2014; Allard et al. 2014).

Yet the case studies demonstrate the intensity of politics that manifests in these instancesperhaps because of, rather than despite, the smallness and tightness of the communities, amongst other island characteristics. Consequently, improved information and less uncertainty do not straightforwardly lead to better communication or more harmonious acceptance of decision-making processes and of decisions. One fundamental point is the need to engage with -not just consult-local populations regarding risk communication and decision-making, tailoring messages to the various audiences, and being clear regarding what is known and not known, plus what is feasible to do to fill in knowledge gaps to support decisions. Activities to engage citizens in the science emerged to a large degree in the three case studies, suggesting that further possibilities be investigated, based on literature and past work in this area (e.g. Cadag and Gaillard 2012; DFID 2003; Kelman et al. 2015; Mercer and Kelman 2010; Texier-Teixeira et al. 2013). Examples of activities are collecting data, mapping exposure and vulnerability, assisting with communication, and organising town hall meetings between scientists and citizens - all of which should happen before a crisis so that a crisis simply continues this work and the long-standing relationships, rather than starting anew during the most difficult time period. Methods exist for melding knowledge forms to ensure that local knowledge and non-local knowledge are treated equally, helping to garner respect and turn information conveyance into information exchange (Mercer et al. 2009) - a process implemented for a volcanic crisis in Papua New Guinea (Mercer et al. 2010).

Ultimately, this becomes a collaboration with communities to ensure that no party or knowledge dominates, but instead information is exchanged leading to decisions and decisionmaking processes which are better understood and accepted by all who are involved. That is, living with volcanic risk means working with communities on their terms.

Acknowledgements We would like to thank first and foremost the communities and authorities on the three case-study islands, who have supported studies of volcanic hazard and risk communication and perception on the islands. SFJ would like to thank João Fonseca, Bruno Faria and Simon Day and colleagues at the Laboratory for Civil Engineering of Cape Verde for providing information and field support at Fogo volcano. The work presented in this chapter was supported by the CASAVA Project (Agence Nationale pour la Recherche, ANR-09-RISK-02: JCK), the MIAVITA Project (EU FP7-ENV contract 211393: SFJ) and an AXA Research Fund fellowship (SFJ). JCK is grateful for stimulating and insightful discussions with M. Devès, F. Beauducel, T. Hincks, W. Aspinal, F. Leone, D. Grancher, M. Redon, M. Chenet and the participants of the CASAVA Consortium. JM is grateful to Patrick Bachèlery, Anthony Finizola, Nicolas Villeneuve, Magali Smietana and Hamidou Nassor from La Réunion Island University, Christopher Gomez from Christchurch University, Hamid Soule from OVK, and the AMISEC forces for their logistic support on Karthala volcano. We gratefully acknowledge the editors who invited us to contribute to this volume. This is IPGP contribution 3695.

Open Access This chapter is distributed under the terms of the Creative Commons Attribution-NonCommercial 4.0 License (http://creativecommons.org/licenses/by-nc/4. $0 /$ ), which permits any noncommercial use, duplication, adaptation, distribution, and reproduction in any medium or format, as long as you give appropriate credit to the original author(s) and the source, a link is provided to the Creative Commons license, and any changes made are indicated. The images or other third party material in this chapter are included in the work's Creative Commons license, unless indicated otherwise in the credit line; if such material is not included in the work's Creative 
Commons license and the respective action is not permitted by statutory regulation, users will need to obtain permission from the license holder to duplicate, adapt, or reproduce the material.

\section{References}

Allard P, Aiuppa A, Beauducel F, Calabrese S, Di Napoli R, Crispi O, Gaudin D, Parello F (2014) Steam and gas emission rate from La Soufriere volcano, Guadeloupe (Lesser Antilles): implications for the magmatic supply during degassing unrest. Chem Geol 384:76-93

Annen C, Wagner J-J (2003) The impact of volcanic eruptions during the 1990s. Nat Hazards Rev 4(4): $169-175$

Aspinall W (2010) A route to more tractable expert advice. Nature 463:294-295

Aspinall WP, Cooke R (2013) Expert Elicitation and Judgement. In: Hill L, Rougier JC, Sparks RSJ (eds) Risk and uncertainty assessment in natural Hazards. Cambridge University Press, Cambridge, pp 64-99

Aspinall WP, Blong R (2015) Chapter 70: volcanic risk assessment. In: H Sigurdsson, B Houghton, S McNutt, H Rymer, J Stix (eds) The Encyclopedia of volcanoes, 2nd edn. Elsevier, Academic Press, Amsterdam. doi:10.1016/B978-0-12-385938-9.01001-4

Bachèlery P, de Coudray J (1993) Carte volcano-tectonique (1/50000e) de la Grande Comore et notice explicative, République Fédérale Islamique des Comores, Centre national de documentation et de recherches scientifiques/République Française, Université de La Réunion, Département Sciences de la Terre, Saint-Denis de La Réunion, France

Barclay J, Haynes K, Mitchell T, Solana C, Teeuw R, Darnell A, Crosweller HS, Cole P, Pyle D, Lowe C, Fearnley C, Kelman I (2008) Framing volcanic risk communication within disaster risk reduction: finding ways for the social and physical sciences to work together. In: DGE. Liverman, CPG Pereira, B Marker (eds) Communicating environmental geoscience, Geological Society of London special publications, Geological Society of London, London, pp 163-177

Beauducel F (2006) A propos de la polémique de La Soufrière 1976. Available: http://www.ipgp.jussieu.fr/ $\sim$ beaudu/soufriere/forum76.html. Accessed 10 June 2015

Blérald A-P (1986) Histoire éruptive de la Guadeloupe et de la Martinique du XVIIème siècle à nos jours. Editions Karthala, Paris

Boichu M, Villemant B, Boudon G (2011) Degassing at La Soufrière de Guadeloupe volcano (Lesser Antilles) since the last eruptive crisis in 1976-77: result of a shallow magma intrusion. J Volcanol Geotherm Res 202:102-112

Bulletin of the Global Volcanism Network (1995) 03/1995 (BGVN 20:03) New eruption on 2 April generates lava flows within the caldera
Cadag JRD, Gaillard JC (2012) Integrating knowledge and actions in disaster risk reduction: the contribution of participatory mapping. Area 44(1):100-109

Chouaybou K (2010) Les risques volcaniques en Grande Comore, Master 2 Géographie, Université Paris 8. France, Paris

de Boer JZ, Sanders DT (2002) Volcanoes in human history. Princeton University Press, Princeton

Da Cruz V, Fengler W, Schwartzman A (2004) Remittances to comoros-volume, trends, impact and implications. Africa Region Working Paper Series, vol 75, pp 1-37

Day SF, Faria BVE (2009) A geological hazard map of the Island of Fogo showing broad distribution of volcanic and other hazards. MIA-VITA Workshop, São Filipe, Fogo

Day SJ, Heleno da Silva SIN, Fonseca JFBD (1999) A past giant lateral collapse and present-day flank instability of Fogo, Cape Verde Islands. Jour Volcanol Geotherm Res 94(1-4):191-218

De Vanssay B (1979) Les événements de 1976 en Guadeloupe: apparition d'une subculture du désastre. Centre Universitaire Antilles-Guyane (Pointe-à-Pitre, Guadeloupe) et Ecole des Hautes Etudes en Sciences Sociales, Université Paris 5, Thèse de Doctorat de 3ème cycle, pp 170. 7 Dec 1979

Devès MH, Ribémont T, Komorowski J-C (2015) Quand les sciences de la Terre rencontrent l'analyse de l'action publique: Retour sur les expériences des éruptions de la Soufrière de Guadeloupe et de Soufrière Hills (Montserrat). CoSPoF 2015, ST 18 "La science politique face aux objets complexes: pratiquent et défis de l'interdisciplinarité. 1-21 pages. Paper presented at the CoSPoF 2015, 6ème Congrès International des Associations Francophones de Science Politique, 5-7 February 2015, Institut d'études politiques et internationales, Université de Lausanne, Switzerland

DFID (2003) Communication during volcanic emergencies - an operations manual for the Caribbean. DFID Project R7406: Protecting small islands by improving forecasting and warning. Department for International Development, pp 37

Dorel J, Feuillard M (1980) Note sur la crise sismo-volcanique à la Soufriére de la Guadeloupe 1975-1977. Bull Volcanol 43(2):419-430

Faria B, Fonseca J (2014) Investigating volcanic hazard in Cape Verde Islands through geophysical monitoring: network description and first results. Nat Hazards Earth Syst Sci 14:485-499

Farugia L (1977) Soufrière 76. Edition Jeunes Antilles, pp 352

Feuillard M, Allègre C, Brandeis G, Gaulon R, Le Mouël J-L, Mercier J, Pozzi J, Semet M (1983) The 1975-1977 crisis of La Soufrière de Guadeloupe (FWI): A still-born magmatic eruption. our Volcanol Geotherm Res 16:317-334

Feuillard M (2011) La Soufrière de la Guadeloupe: un volcan et un peuple. Guadeloupe, Editions Jasor, Pointe-à-Pitre, p 246 
Fiske RS (1984) Volcanologists, journalists, and the concerned local public: a tale of two crises in the eastern Caribbean. In: Geophysics Study Committee, Geophysics Research Forum, Commission on Physical Sciences, Mathematics, and Ressources, National Research Council, (eds) Explosive Volcanism. Inception, Evolution and hazards. Studies in Geophysics. National Academy Press, Washington, DC, p 170176

Fonseca JFBD, Faria BVE, Lima NP, Heleno SIN, Lazaro C, d'Oreye NF, Ferreira AMG, Barros IJM, Santos P, Bandomo Z, Day SF, Osorio JP, Baio M, Matos JLG (2003) Multiparameter monitoring of Fogo Island, Cape Verde, for volcanic risk mitigation. J Volcanol Geotherm Res 2605:1-18

Gaillard JC (2008) Alternative paradigms of volcanic risk perception: the case of Mt Pinatubo in the Philippines. J Volcanol Geoth Res 172(3-4):315-328

Gaillard JC, Mercer J (2013) From knowledge to action Bridging gaps in disaster risk reduction. Prog Hum Geogr 37(1):93-114

Global Volcanism Program (2014) Weekly Reports: 3 to 9 December 2014, Weekly Reports of the Global Volcanism Network. Smithsonian Institution, Washington DC

Hincks TK, Komorowski J-C, Sparks RSJ, Aspinall W (2014) Retrospective analysis of uncertain eruption precursors at La Soufrière volcano, Guadeloupe, 197577: volcanic hazard assessment using a Bayesian Belief Network approach. J Appl Volcanol 3:1-26

https://sites.google.com/site/casavaanr/, Web-page of the CASAVA project, Understanding and assessing volcanic hazards, scenarios, and risks in the Lesser Antilles: implications for decision-making, crisis management, and pragmatic development, ANR-RISK-09-002; 2010-2014, Agence Nationale pour la Recherche, Paris, France, last accessed 10 June 2015

http://www.ipgp.fr/fr/ovsg/bulletins-mensuels-de-lovsg. Last accessed 10 June 2015

http://www.ipgp.fr/fr/ovsg/actualites-ovsg. Last accessed 10 June 2015

http://www.ipgp.fr/fr/ovsm/bilans-trimestriels-de-lovsm. Last accessed 10 June 2015

Jenkins SF, Spence RJS, Fonseca JFBD, Solidum RU, Wilson TM (2014) Volcanic risk assessment: Quantifying physical vulnerability in the built environment. J Volcanol Geotherm Res 276:105-120

Keesing FM (1952) The Papuan Orokaiva vs. Mt Lamington: Cultural Shock and its Aftermath, Human Organization 11(1):26-22

Kelman I, Lewis J, Gaillard JC, Mercer J (2011) Participatory action research for dealing with disasters on islands. Isl Stud J 6(1):59-86

Kelman I, Gaillard J-C, Mercer J, Crowley K, Marsh S, Morin J (2015) Culture's role in disaster risk reduction. Combining knowledge systems on Small Island Developing States (SIDS). Cultures and disasters, p 208-219 (in press)
Kokelaar BP (2002) Setting, chronology and consequences of the eruption of Soufrière Hills Volcano, Montserrat (1995-1999) In: Druitt TH, Kokelaar BP (eds) The eruption of Soufrière Hills Volcano, Montserrat, from 1995 to 1999 . Mem Geol Soc Lond 21:1-44

Komorowski J-C, Boudon G, Semet M, Beauducel F, Anténor-Habazac C, Bazin S, Hammouya G (2005) Guadeloupe. In: Lindsay JM, Robertson REA, Shepherd JB, Ali S (eds) Volcanic Hazard Atlas of the Lesser Antilles. Seismic Research Unit, The University of the West Indies, Trinidad and Tobago, pp 65102

Komorowski J-C, Beauducel F, Hincks T, Aspinall W, Sparks RSJ, Villemant B, Boudon G (2012) Lessons learned from the 1975-77 unrest-failed magmatic eruption at la Soufrière of Guadeloupe (West indies): implications for future unrest-eruption forecast planning and response, Invited Keynote speech, VUELCO workshop, "Volcanic unrest: uncertainties and scenario planning/forecasting», Sunday 18 November, Cities on Volcanoes 7, 18-23 November 2012, IAVCEI, Colima, Mexico, abstract, oral

Komorowski J-C, Legendre Y, Barsotti S, Esposti Ongaro T, Jenkins S, Baxter P, Boudon G, Leone F, Neri A, Spence R, Aspinall W, Grancher D, Redon M, Chopineau C, de Chabalier J-B (2013a) Assessing long term hazards for la Soufriere of Guadeloupe volcano: insights from a new eruptive chronology, credible scenario definition, and integrated impact modelling. International Association of Volcanology and Chemistry of the Earth's Interior (IAVCEI), Scientific Assembly, Kagoshima, Japan, 19-24 Juy 2013, abstract, 4W_4D-P1, poster

Komorowski J-C, Beauducel F, Leone F. Redon M, Chopineau C, Bengoubou-Valerius $\mathrm{M}$, and the CASAVA research consortium (C Antenor, W Aspinall, MD Baillard, S Barsotti, P Baxter, A Bitoun, G Boudon, M Burac, L Bruxelles, G Carazzo, J-B de Chaballier, M Chenet, A Chevallier, V Clouard, J-C Denain, C Dessert, T Esposti Ongaro, N Feuillet, S Fourmond, M Gherardi, D Grancher, J-R Gros-Desormeaux, T Hincks, S Jenkins, E Kaminski, A Le Friant, G Lalubie, F Lavigne, Y Legendre, T Lesales, M Mas, J-M Mompelat, J Morin, C Narteau, A. Neri, S Pelczar, R Robertson, S Sparks, R Spence, $\mathrm{P}$ Tinard, B Villemant, F Vinet, G Woo) (2013b) The scientific challenges of responding to potential eruptive scenarios at La Soufrière of Guadeloupe: Lessons learned from the 1975-77 unrest failed-magmatic eruption and insights from integrated interdisciplinary risk assessment in the framework of the CASAVA project, 42nd Workshop of the International School of Geophysics, Volcano Observatory Best Practices Workshop \#2: Communicating Hazards, INGV and USGS, Erice, Sicily (IT), 02-06 Nov 2013, invited oral

Komorowski J-C, Beauducel F, Devès M, Dessert C, de Chabalier J-B, and the CASAVA research consortium (2014) Failed magmatic eruptions, uncertain 
precursors and false alarms: lessons learned from the 1976-77 La Soufrière of Guadeloupe volcano (French Antilles) crisis, Workshop of the Cost Action IS1304, "Expert Judgment Network: Bridging the Gap Between Scientific Uncertainty and Evidence-Based Decision Making". "Science, uncertainty and decision making in the mitigation of natural risks" Dipartimento della Protezione Civile, Roma October 8-9-10, 2014, invited oral, http://www.expertsinuncertainty. net/

Komorowski J-C, Hincks T, Sparks RSJ, Aspinall W, and the CASAVA ANR project consortium (2015) CS5. Improving crisis decision-making at times of uncertain volcanic unrest (Guadeloupe, 1976). In: Brown SK, Loughlin SC, Sparks RSJ, Vye-Brown C et al (eds) Global volcanic hazards and risk, summary background paper for the UN-ISDR Global Assessment of Risks 2015 (GAR15) A report by the Global Volcano Model and the International Association of Volcanology and Chemistry of the Earth's Interior, pp 114-119. http://www.preventionweb.net/english/ hyogo/gar/2015/en/bgdocs/GVM,\%202014b.pdf

Lepointe E (1984) Essai sur la réponse sociale à une catastrope: La Soufrière de Guadeloupe en 1976, Thèse Doctorat d'Etat, Université Paris 10, Nanterre, vol 1 (pp 1-445) and vol 2 (pp 447-975)

Lepointe E (1999) Le réveil du volcan de la Soufriére en 1976: la population guadeloupéenne à l'épreuve du danger. In: Yacou A (ed) Les catastrophes naturelles aux Antilles-D'une Soufriére à l'autre. CERC Université Antilles et de la Guyane, Editions Karthala, Paris, pp 15-71

Lewis J (1999) Development in disaster-prone places: studies of vulnerability. Intermediate Technology Publications, London

Lewis J (2009) A island characteristic. Derivative vulnerabilities to indigenous and exogenous hazards. Shima: Int J Res Isl Cult 3(1):3-15

Loubat B, Pistolesi-Lafont A (1977) La Soufrière-à qui la faute ?. Presses de la Cité, Paris, p 220

Méheux K, Dominey-Howes D, Lloyd K (2007) Natural hazard impacts in small island developing states: a review of current knowledge and future research needs. Nat Hazards 40(2):429-446

Mercer J, Kelman I (2010) Living alongside a volcano in Baliau, Papua New Guinea”. Disaster Prev Manag 9 (4):412-422

Mercer J, Kelman I, Suchet-Pearson S, Lloyd K (2009) Integrating indigenous and scientific knowledge bases for disaster risk reduction in Papua New Guinea. Geografiska Annaler: Series B, Hum Geogr 91(2): $157-183$

Morin J (2012) Gestion institutionnelle et réponses des populations face aux crises volcaniques : études de cas à La Réunion et en Grande Comore. Thèse de doctorat, Université de La Réunion, Saint-Denis, La Réunion pp 368 (+annexes 88 pp)

Morin J, Gaillard J-C (2012) Lahar hazard and livelihood strategies on the foot slopes of Mt Karthala volcano, Comoros. In: Wisner B, Gaillard J-C, Kelman I (eds) Handbook of hazards and disaster risk reduction. Routledge, London, pp 705-706

Morin J, Lavigne F (2009) Institutional and social responses to hazards related to Karthala volcano, Comoros-part II: the deep-seated root causes of Comorian vulnerabilities. SHIMA: Int J Res Isl Cult 3-1:54-71

Morin J, Lavigne F, Bachèlery P, Finizola A, Villeneuve N (2009) Institutional and social responses to hazards related to Karthala volcano, Comoros - part I: analysis of the May 2006 eruptive crisis. SHIMA: Int J Res Isl Cult 3-1:33-53

Morin J, Bachèlery P, Soule S, Nassor H (2016) Volcanic risk and crisis management on Grande Comore Island. In: Bachelery P, Lenat J-F, Di Muro A, Michon L (eds) Active Volcanoes of the Southwest Indian Ocean: Piton de la Fournaise and Karthala, Active Volcanoes of the World, Springer-Verlag, Berlin, Heidelberg, pp 208-221, doi: 10.1007/978-3-64231395-0_24

Nassor H (2001) Contribution à l'étude du risque volcanique sur les grands volcans boucliers basaltiques: le Karthala et le Piton de la Fournaise, unpublished PhD dissertation, University of La Réunion pp 218

Oraison A (2004) La mise en place des institutions de 1 ' «Union des Comores» prévues par la Constitution du 23 décembre 2001. L'avènement d'un régime de type présidentiel et fédéral dans un état francophone du canal de Mozambique Revue française de Droit Constitutionnel 4-60:771-795

OVSG-IPGP (2015) Le bilan annuel 2014 de l'activité volcanique de la Soufrière et de la sismicité régionale. http://www.ipgp.fr/fr/ovsg/actualites-ovsg. Last accessed 10 June 2015

Pattullo P (2000) Fire from the Mountain: the tragedy of montserrat and the betrayal of its people. Constable and Robinson, London

Pelling M, Uitto JI (2001) Small island developing states: natural disaster vulnerability and global change. Environ Hazards 3:49-62

Préfecture de Guadeloupe (1977) Volcan de la Soufrière en Guadeloupe: les événements de 1976. Service d'information de la Préfecture de Guadeloupe, janvier 1977, Basse-Terre, Guadeloupe pp 50

Ribeiro O (1960) A ilha do Fogo e as suas erupções. Junta de Investigaçôes do Ultramar

Taglioni F (2003) Recherches sur les petits espaces insulaires et sur leurs organisations régionales. Mémoire d'HDR, Université Paris IV-Sorbonne, Paris 218

Texier-Teixeira P, Chouraqui F, Perrillat-Collomb A, Lavigne F, Cadag JR, Grancher D (2013) Reducing volcanic risk on Fogo Volcano, Cape-Verde, through a participatory approach: which out coming? Nat Hazards Earth Syst Sci 1:6559-6592

UNDP (2014) Human development reports. http://hdr. undp.org/fr/content/table-1-human-developmentindex-and-its-components

Union des Comores (2004) Plan National de Préparation et de Réponse à l'urgence. Union des Comores, Moroni, p 68 
Villemant B, Hammouya G, Michel A, Semet M, Komorowski J-C, Boudon G, Cheminée J-L (2005) The memory of volcanic waters: shallow magma degassing revealed by halogen monitoring in thermal springs of La Soufrière volcano (Guadeloupe, Lesser Antilles), Earth Planet. Sci. Letters 237:710-728

Villemant B, Komorowski J-C, Dessert C, Michel A, Crispi O, Hammouya G, Beauducel F, de Chabalier JB (2014) Evidence for a new shallow magma intrusion at
La Soufrière of Guadeloupe (Lesser Antilles). Insights from long-term geochemical monitoring of halogen-rich hydrothermal fluids. J Volcanol Geotherm Res 285:247-277

Weichselgartner J (2003) Toward a policy-relevant hazard geography: critical comments on geographic natural hazard research. Erde 134(2):181-193

Woo G (2011) Calculating catastrophe. Imperial College Press, London, p 355 